\title{
PEMANFAATAN COMPUTATIONAL FLUID DYNAMICS (CFD) DALAM STRATEGI PENELITIAN SIMULASI MODEL PADA TEKNOLOGI PENGHAWAAN RUANG
}

\author{
Sherlly Maulana ${ }^{1}$ \\ ${ }^{1}$ Dosen Fakultas Teknik, Universitas Medan Area \\ (maulanasherlly@gmail.com)
}

\begin{abstract}
ABSTRAK
Studi ini bertujuan untuk melakukan tinjauan pustaka terhadap penggunaan teknologi komputer, khususnya penggunaan simulasi Computational Fluid Dynamics (CFD) pada pengembangan strategi rancangan penghawaan alami. Media CFD mengsimulasikan gerak fluida berdasarkan pada suatu kondisi dengan menggunakan dasar-dasar perhitungan fluida bergerak. Simulasi CFD dilakukan melalui tiga tahapan, yaitu preprocessing, solving, dan postprocessing, yang menggunakan perhitungan matematika dalam menentukan kondisi batasan fluida pada obyek penelitian. Hasil simulasi CFD pada lingkup penelitian ini digunakan untuk memprediksi pergerakan angin di sekitar bangunan dan di dalam bangunan, sehingga dapat mengurangi tingkat kegagalan rancangan ventilasi alami pada bangunan. Pengembangan metode simulasi CFD perlu ditingkatkan, terutama dalam hal tingkat akurasi hasil penelitian. Saat ini, simulasi CFD masih memerlukan data pembanding untuk menilai akurasi hasil simulasi CFD.
\end{abstract}

Kata Kunci : Abu penghawaan alami, bangunan, fluida bergerak, simulasi CFD

\begin{abstract}
This study aims to conduct a literature review on the use of computer technology, especially the use of simulation Computational Fluid Dynamics (CFD) on the development of natural penghawaan draft strategy. Media CFD mengsimulasikan fluid motion based on a condition by using the basics of computation fluid move. CFD simulation is performed through three stages: preprocessing, solving, and postprocessing, which uses mathematical calculations to determine the condition of the fluid limits on the object of study. CFD simulation results in the scope of this research are used to predict the movement of the wind around the building and inside the building, so as to reduce the failure rate design of natural ventilation in buildings. Development of CFD simulation methods need to be improved, especially in terms of the accuracy of the results. Currently, CFD simulations still require comparative data to assess the accuracy of CFD simulation results.
\end{abstract}

Keywords: Abu penghawaan naturally, the building, the fluid moves, CFD simulation

\section{Pendahuluan}

Indonesia sebagai salah satu negara tropis memiliki kesulitan dalam menciptakan kenyamanan termal ruang. Bentuk dan model bangunan yang tidak mampu beradaptasi dengan kondisi iklim mendorong pengguna bangunan untuk menggukanan teknologi penghawaan ruang secara mekanik, seperti alat pengkondisian udara (air conditioning). Kondisi ini mendorong peningkatan jumlah pemakaian listrik untuk rumah tangga yang mencapai $40 \%$ konsumsi listrik dunia (Santamouris, 2005).
Pengembangan alternatif rancangan untuk mengurangi penggunaan energi listrik pada pada bangunan berkembang sangat pesat. Penelitian lebih difokuskan kepada penerapan ventilasi alami pada bangunan dengan tujuan untuk mengurangi beban panas pada bangunan. Kubota dkk (2010) menyatakan bahwa pengurangan konsumsi energi dan emisi gas rumah kaca merupakan keuntungan penggunaan ventilasi alami pada bangunan. Keuntungan penggunaan penghawaan alami pada bangunan adalah: 1) mengurangi biaya operasional bangunan; 2) meningkatkan tingkat kenyaman termal ruang; 
dan 3) kualitas udara yang lebih baik (Aflaki dkk, 2015).

Penelitian untuk mengembangkan alternatif strategi rancangan penghawaan alami bangunan berkembang pesat sesuai dengan perkembangan teknologi dan ilmu pengetahuan. Selain mendapatkan model rancangan penghawaan yang optimal, penelitian juga diarahkan untuk mengembangkan metode-metode penelitian untuk menguji atau mengembangkan teoriteori yang berhubungan dengan penghawaan alami pada bangunan.

Studi ini bertujuan untuk melakukan tinjauan pustaka terhadap penggunaan teknologi komputer, khususnya penggunaan simulasi Computational Fluid Dynamics (CFD) dalam pengembangan metode penelitian pada strategi rancangan penghawaan alami bangunan. Strategi penelitian simulasi model menjadi strategi penelitian yang dipilih dalam pembahasan

\section{Strategi Simulasi Model Pada Riset Arsitektur}

Simulasi dan model pada riset arsitektur digunakan sebagai salah satu strategi penelitian yang berhubungan dengan skala ruang dan kerumitan lingkup penelitian. Secara umum, strategi simulasi dan model dapat digunakan dalam pengembangan teori atau menguji suatu teori (Groat dan Wang, 2002).

Strategi simulasi model berkembang dalam kegiatan penelitian yang membutuhkan argumentasi logis, eksperimental riset, dan korelasi riset. Clipson pada Groat dan Wang (2002) membagi simulasi model menjadi empat tipe: iconic, analog, operational, dan mathematical. Ikonik dan analog digunakan jika obyek penelitian berhubungan langsung dengan konteks fisik. Ikonik digunakan untuk melakukan uji material atau produk, sedangkan analog digunakan untuk menguji suatu kondisi fisik tertentu. Simulasi model operasional digunakan jika obyek penelitian yang diuji berhubungan dengan interaksi manusia pada suatu kondisi fisik, tetapi lebih menekankan pada pengumpulan data. Model matematika adalah sistem perhitungan yang digunakan untuk mewadahi hubunganhubungan di kehidupan nyata yang bersifat abstrak menjadi nilai-nilai kuantitatif.

Teknologi komputer yang saat ini mengalami perkembangan cukup pesat, terutama dalam hal pengembangan perangkat lunak (software), menjadikan teknologi komputer sebagai perangkat taktis dalam simulasi model. Teknologi komputer memiliki kemampuan untuk meniru kondisi nyata dengan kondisi buatan yang hampir sama, baik pada skala mikro dan makro, sesuai dengan perhitungan operasional yang telah ditentukan. Penggunaan teknologi komputer pada simulasi model memberikan kontribusi positif, terutama untuk mengurangi kesalahan rancangan pada bangunan.

Penggunaan perangkat lunak pada simulasi model untuk penelitian pada teknologi penghawaan ruang antara lain adalah Computational Fluid Dynamics (CFD).

\section{Computational Fluid Dynamics (CFD)}

Simulasi CFD saat ini banyak digunakan sebagai salah satu metode penelitian dalam pengembangan alternatif rancangan penghawaan alami. Hal ini karena simulasi CFD relatif lebih murah dan kondisi batasan obyek penelitian yang mudah dikontrol (Santamouris dan Allard, 1998).

Media CFD mengsimulasikan gerak fluida berdasarkan pada suatu kondisi dengan menggunakan dasar-dasar perhitungan fluida bergerak. Simulasi CFD dapat memprediksi secara rinci pergerakan angin (fluida bergerak) di sekitar obyek penelitian, baik di dalam maupun di luar bangunan. Jiang dan Chen (2001) menyatakan bahwa Large Eddy Simulation (LES) adalah model CFD yang memiliki akurasi hasil terbaik dibandingkan dengan model CFD lainnya untuk kasus obyek penelitian bangunan. Selain itu, hasil analisis CFD mudah untuk dipahami.

Namun demikian, karena model simulasi CFD menggunakan banyak asumsi, akurasi model tersebut harus divalidasi dengan menggunakan data eksperimen lainnya sebagai pembanding, seperti on-site experiment, wind-tunnel experiment, dan perhitungan matematika (numerical validation).

Simulasi CFD dilakukan melalui tiga tahapan, yaitu preprocessing, solving, dan postprocessing (Tuaika, 2008). Preprocessing merupakan pembuatan model obyek penelitian dengan format Computer Aided Design (CAD), membuat mesh sesuai desain, kemudian meenerapkan kondisi batas dan sifat fluidanya. Solvers (program inti pencari solusi) CFD menghitung kondisi-kondisi yang diterapkan 


\section{Pemanfaatan Computational Fluid Dynamics (CFD) Dalam Strategi Penelitian Simulasi Model Pada Teknolgi Penghawaan Ruang}

pada saat preprocessing. Sementara itu, Postprocessing adalah langkah terakhir dalam analisis CFD. Hal yang dilakukan pada langkah ini adalah mengorganisasi dan menginterpretasi data hasil simulasi CFD berupa gambar, kurva, atau animasi.

Bu dan Kato (2011) melakukan penelitian tentang efektifitas ventilasi satu sisi karena pergerakan angin pada area berkepadatan tinggi (bangunan tingkat tinggi) dengan building coverage area $33 \%$ melalui simulasi CFD dengan model LES (Large-eddy Simulation) (Gambar 1 dan 2). Maulana, dkk (2013) menggunakan simulasi CFD dengan model Spallart-Allamars pada penelitian dampak perancangan tapak pada kinerja ventilasi satu sisi di bangunan rumah tinggal di Medan (Gambar 3 dan 4). Hasil simulasi CFD menunjukkan arah dan kecepatan pergerakan angin pada tapak dan sekitar bangunan

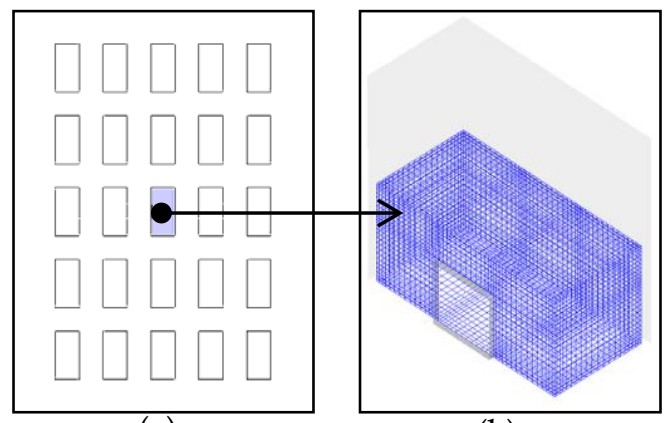

(a)

(b)

Gambar 1. Model penelitian Bu dan Kato (2011)

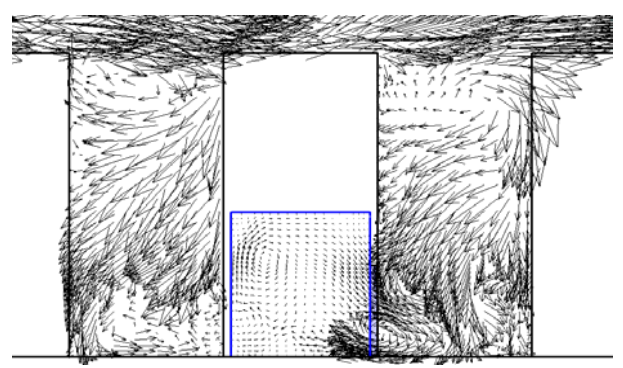

(a)

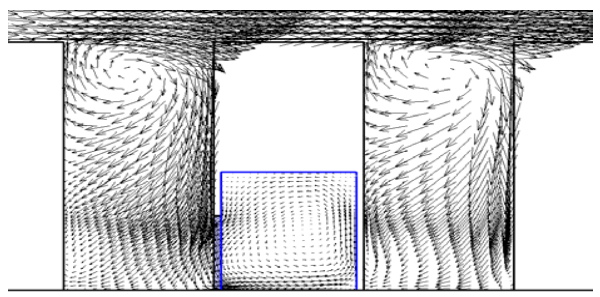

(b)

Gambar 2. Hasil simulasi CFD Penelitian $\mathrm{Bu}$ dan Kato (2011)

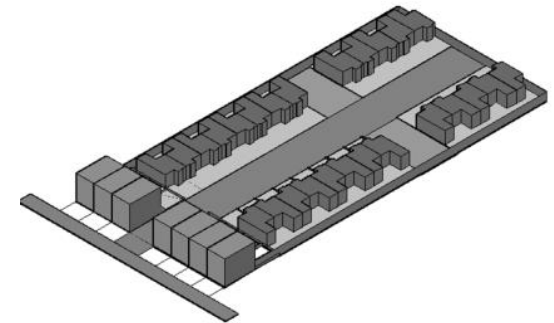

Gambar 3. Model tapak obyek penelitian Maulana, dkk (2013)
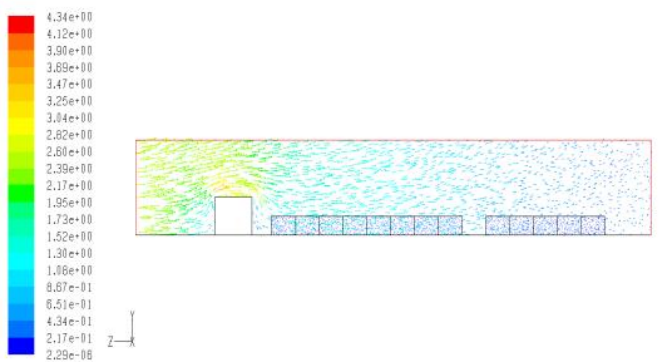

Gambar 4. Hasil simulasi CFD pada obyek penelitian (Maulana, dkk, 2013)

Selain obyek penelitian di tingkat skala mikro (skala tapak), simulasi CFD optimal digunakan pada obyek penelitian ruang dalam bangunan (indoor). Shetabivash (2015) menggunakan simulasi CFD dengan model direct numerical simulation (DNS) dan model Reynolds Averaged Navier-Stokes (RANS) sebagai data pembanding. Simulasi ini digunakan untuk meneliti letak dan bentuk bukaan pada ventilasi silang. Simulasi dilakukan dengan membuat beberapa alternatif peletakan bukaan pada bangunan yang diuji untuk melihat pergerakan angin yang optimal pada ruangan (Gambar 5).
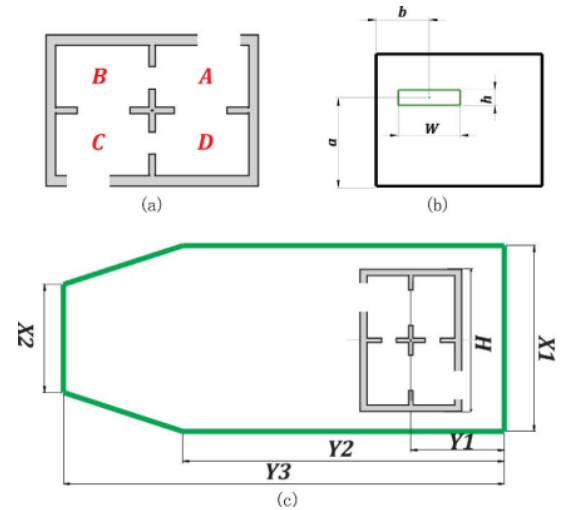

a) Denah bangunan, b) dimensi rencana tapak, c) posisi bukaan pada bangunan

Gambar 5. Obyek penelitian Shetabivash (2015 


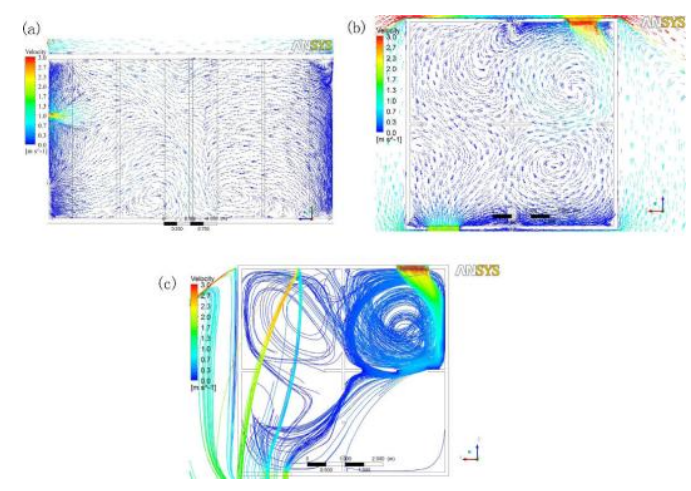

Gambar 6. Salah satu hasil simulasi CFD pada penelitian Shetabivash (2015)

\section{Kesimpulan}

Penggunaan teknologi komputer, khususnya Computational Fluid Dynamics (CFD), pada strategi simulasi model dalam penelitian rancangan penghawaan alami pada bangunan merupakan salah satu kemajuan teknologi informasi yang digunakan dalam mengembangkan metode penelitian teknologi bangunan. Hasil simulasi CFD dapat digunakan untuk memprediksi pergerakan angin di sekitar bangunan, sehingga dapat mengurangi tingkat kegagalan rancangan ventilasi pada bangunan. Pengembangan simulasi CFD perlu ditingkatkan, terutama dalam hal tingkat akurasi hasil penelitian.

\section{Daftar Pustaka}

Aflaki A, dkk, 2015, A review on natural ventilation application through building facade components and ventilation openings in tropical climates, Jurnal Energy and Buildings 101, hal. 153-162

Groat L dan Wang D, 2002, Architectural Research Methods 1st Edition, Wiley, Washington

Maulana. S, Ramdan. D, Siregar. N. A, 2013, Impact of Site Design To Single-sided Ventilation Performance on Residential Building in Medan, Proceiding International Conference on Policy and Technology for Affordable Housing, Medan

M. Santamouris, 2005, Energy in the urban built environment: The role of natural ventilation, Natural ventilation in the urban environment: assesment and design, hal. 119
M. Santamouris, F. Allard, 1998, Natural Ventilation in Buildings: A Design Handbook, James \& James, London, UK.

T. Kubota, D.T.H Chyee, 2010, Potential of Passive Cooling techniques for modern houses in tropical climate of Malaysiaanalysis of the indoor thermal environment for various ventilation strategies, Int. J. Vent. 9 (1), hal 11-23.

Y. Jiang, Q. Chen, Study of natural ventilation in buildings by large eddy simu-lation, J. Wind Eng. Ind. Aerodyn. 89 (2001) 11551178.

Zhen Bu, Sasaki Kato, 2011, Investigation of Ventilation Effectiveness for Wind-driven Single-Sided Ventilated Buildings Located in Urban Environment, International Journal of Ventilation Vol. 10 No. 1

Shetabivash, H, 2015, Investigation of shape and opening position on natural cross ventilation, Energy and buildings 93, hal 115 